Research CommentaRies: Food Systems Research Priorities over the NeXt 5 Years

\title{
The next food systems agenda: A western grassroots perspective
}

\author{
V. Philip Rasmussen, ${ }^{a *}$ Stacie Clary, ${ }^{\mathrm{b}} \mathrm{Al}$ Kurki, ${ }^{\mathrm{c}}$ and Ron Daines ${ }^{\mathrm{d}}$ \\ Western Sustainable Agriculture Research and Education (SARE) Center
}

Submitted July 16, 2013 / Revised September 24, 2013 / Published online September 27, 2013

Citation: Rasmussen, V. P., Clary, S., Kurki, A., \& Daines, R. (2013). The next food systems agenda: A western

grassroots perspective. Journal of Agriculture, Food Systems, and Community Development, 3(4), 235-247.

http://dx.doi.org/10.5304/jafscd.2013.034.030

Copyright (C) 2013 by New Leaf Associates, Inc.

\begin{abstract}
The national United States Department of Agriculture (USDA)'s National Institute for Food and Agriculture (NIFA) Sustainable Agriculture
\end{abstract}

\footnotetext{
a * Corresponding author: V. Philip Rasmussen, Director, Western SARE Center, Utah State University; 4865 Old Main Hill; Logan, Utah 84322-4865 USA; +1-435-797- 2257; philip.rasmussen@usu.edu

b Stacie Clary, Communications Specialist, Western SARE Center; 706 Gilroy Drive; Capitola, California 95010 USA; +1-831-419-5432; stacie.wsare@,charter.net

c Al Kurki, PDP Program Associate Training Coordinator, Western SARE Center; 432 North Last Chance Gulch; Helena, Montana 59601 USA; 406-494-8655; akurki@ncat.org

d Ron Daines, former Communications Specialist, Western SARE Center; 40 Heritage Cove; Logan, Utah 84321 USA; +1-435-770-3063; rjdaines@msn.com
}

Note: Support for this project was provided by the national United State Department of Agriculture National Institute for Food and Agriculture's (USDA-NIFA) Sustainable Agriculture Research and Education (SARE) program office. The authors were or are full- or part-time employees of the Western Region Sustainable Agriculture Research and Education (SARE) Center.
Research and Education (SARE) program celebrates its twenty-fifth year of operation in 2013. At this critical juncture, the Western SARE Center is now addressing what it considers to be key food systems development priorities in the years ahead. They include:

- Gaps in and lack of infrastructure development;

- Consumer education on the benefits and preparation of sustainable, locally grown foods;

- Changes in policy, regulations, institutional purchasing, and financing that are more supportive of and a catalyst for local food system development; and

- Training for beginning farmers and ranchers.

In this research commentary, we share how Western SARE arrived at these priorities, based on extensive grassroots input. Further, we outline to what extent these priorities may be a part of a larger, longer-term research agenda in food systems. 


\section{Keywords}

beginning farmers, consumer education, funding, infrastructure development, policy, processing, regulation, sustainability, sustainable agriculture, value-added

\section{Introduction and Background}

As it neared its twentieth anniversary in 2008, Western SARE had disbursed more than US\$69 million to fund more than 1,110 grants. These competitive grants funded research and provided research-based education about sustaining the West's agriculture. This grant-making process reflected the West's research and education needs to some degree, but only as understood by the people who knew about the United States Department of Agriculture's National Institute for Food and Agriculture SARE (USDA-NIFA-SARE) program and had the motivation to apply. SARE's twentieth anniversary presented Western SARE leaders with an opportune time to identify significant changes that could be fully implemented by its twenty-fifth anniversary in 2013.

In appraising its successes and plotting strategies for the future, the Western SARE Center's staff and administrative council (the congressionally stipulated governing board of directors composed of producers, land-grant university administrators, and other key agricultural leaders) saw a need to more fully grasp the region's evolving issues and constraints. Their desire was to assure that (1) the grant-review process selects quality projects for funding that truly address local and regional needs, and (2) priority issues could be addressed through the release of targeted calls for proposals.

Percolating from these deliberations was the launch of a series of seven listening sessions, dubbed Western SARE's Subregional Conferences, beginning in October 2007 on the island of Guam and concluding in March 2010 in the heart of Alaska. The intent was to engage key stakeholders at the grassroots level in each of seven easily identified subregions within the Western SARE Region. The stated goals of the subregional conferences were to:

1. Identify and prioritize emerging and unmet research and education needs in sustainable food, fiber, and energy systems; and

2. Increase stakeholder and policy-holder awareness of the accomplishments of the Western SARE Center and its projects.

The administrative council and staff harnessed a distinctive combination of needs assessments and educational tools to meet these two goals.

From October 2007 to March 2010, nearly 700 people from the Western SARE region, each with a stake in production agriculture and food systems, voiced more than 7,000 recorded comments about the state of western agriculture and how it can be strengthened and sustained. These comments arose at seven separate subregional conferences within seven distinct geographic zones (Oceania [Agatna, Guam], Southwest [Albuquerque, New Mexico], High Plains [Cheyenne, Wyoming], Pacific Northwest [Spokane, Washington], North Pacific [Hilo, Hawaii], Pacific Coast [Visalia, California], and Subarctic [Fairbanks, Alaska]). The conferences were planned, carefully facilitated, and implemented by the Western SARE Center (a designated regional research center of the USDA-NIFA). The Western SARE Center is headquartered at Utah State University, and its SARE Professional Development Program is headquartered at the University of Wyoming. A broad cross-section of food and farming leaders were invited in order to identify and prioritize research and education needs in sustainable food, fiber, and energy systems.

The extent of the data collected in seven subregional conferences, spanning the globe from Guam to Montana, cannot be adequately portrayed in this commentary. However, a more complete and extensive presentation of all significant data collected at all seven Western SARE Subregional Conferences is available online. ${ }^{1}$

\section{Conference Approach and Methodology}

The overall strategy was to gather grassroots input followed the basic principles of Schmoldt and Peterson (2000) while putting the information to

\footnotetext{
${ }^{1}$ See more about the subregional conferences at http://www.westernsare.org/Conferences/Subregional$\underline{\text { Stakeholder-Conferences }}$
} 
work as described by Glass (1979). The specific method of gathering information in each region used Western SARE's design, which drew on the main elements of the Nominal Group Method (NGM) as defined by Delbecq and Van de Ven (1971), and refined by Delbecq, Van de Ven, and Gustafson (1975), Sample (1984), and Place (2007).

Although this technique required countless hours of staff effort, it was critical to the success of the conferences. It allowed for the distillation of information into priorities for each subregion. Specific details of our methodology are outlined in appendix A.

\section{Results and Discussion}

Seven hundred people from the Western SARE Region who have a stake in production agriculture and food systems (farmers, ranchers, educators, agency personnel, nongovernmental organization leaders, and others) attended the seven Western SARE Subregional Conferences. Attendees generated more than 7,000 individual recorded comments pertaining to the issues and constraints of western agriculture. The number of comments from roundtable discussions ranged between 400 and 800 for each conference, with additional comments recorded in table reports, open-microphone sessions, and surveys during and after the conference.

Sorting and ranking this mountain of data presented a challenge. Western SARE employed a unique process at the conferences to streamline the information in real time on site for use during the conference and in subsequent strategy deliberations. As facilitated table groups worked through the "burning issue" focus questions, responses were recorded on oversized Post-it notepads. Western SARE staff then recorded those responses into Excel spreadsheets where they were categorized, collated, and prioritized, providing real-time turnaround of ranked results from the first day. The first-day results were printed and delivered to participants early the next morning for additional discussion and further prioritization.

There are many other ways to sort and present the "poster pad" issues that received large numbers of votes at any, some, or all conferences. Appendix $\mathrm{B}$ presents the issues that received the highest "votes" (via the nominal group methodology) across all of the conferences.

The following figures provide the overall results for the Western SARE Region for each burning issue focus question across all of the subregional conferences.

\section{BURNING ISSUE 1. What Will Be Needed to Create a Stronger Local and Regional Food System?}

Conference attendees reported that education and improved infrastructure that serves agriculture (processing, transportation, utilities, etc.) are the leading means for creating strong local and regional food systems that are less reliant on imports.

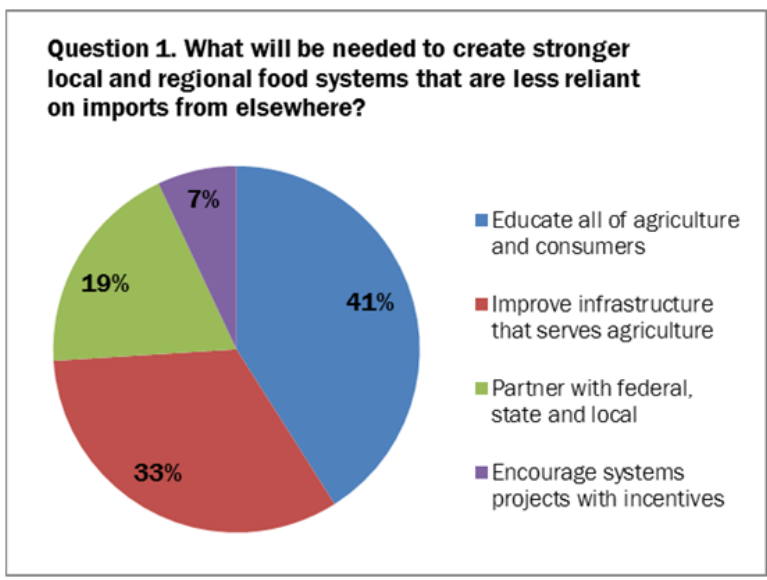

\section{BURNING ISSUE 2. What Are the Local and Regional Trends?}

The most significant trends in the subregional area identified by conference attendees include simultaneous increase in direct markets and a decline in producers. Note that agricultural infrastructure surfaces as both a need (question 1) and a trend.

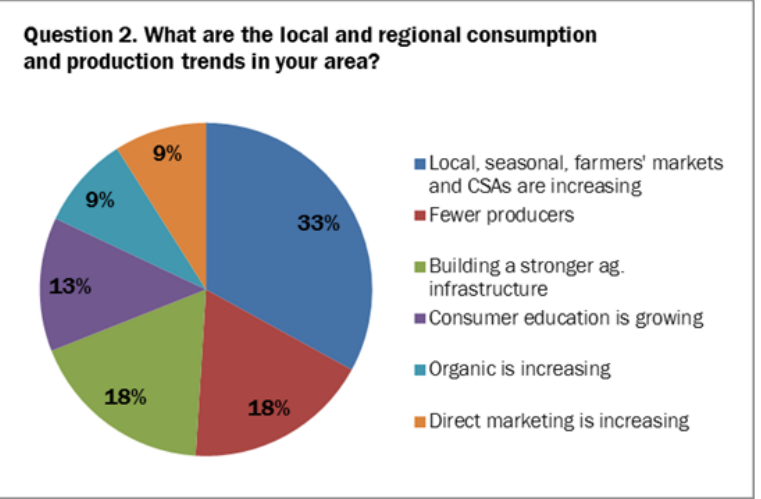


BURNING ISSUE 3. How Can the Process of Disseminating Research Results Be Improved?

Representing about $75 \%$ of the votes, conference attendees felt that Western SARE could improve dissemination the most through three methods: (1) sponsoring or encouraging more conferences workshops, classes, and field days in an on-farm setting; (2) including farmers and ranchers in all SARE projects (emphasized repeatedly and quantified in this graphic); and (3) improving outreach to farm and ranch organizations and publications (also repeatedly emphasized).

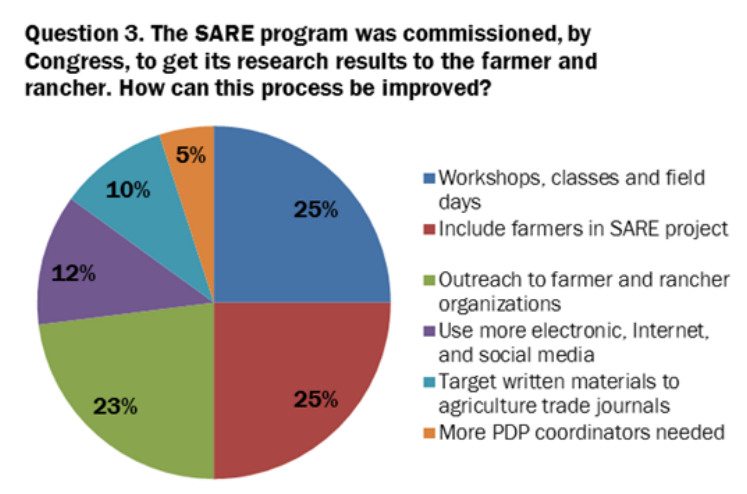

BURNING ISSUE 4. What Research and Education Are Needed in the Next 10 Years? Conference attendees reported a wide range of projects needed, with developing longer-term sustainable farm systems garnering the most votes.

Question 4. What type of research, education and development projects will be necessary over the next 10 years to help economically sustain farming and the environment?

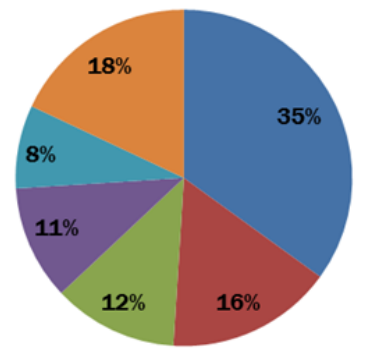

- Develop long-term sustainable farm systems

- Encourage research and education of soils issues

= Agricultural education of public and youth

- Research alternative and sustainable energy

- Increase production value and decrease costs nother

\section{BURNING ISSUE 5. What New Projects} Should Be Targeted?

Again, a wide range of project types was identified by the conference attendees. Education of the public and youth on sustainable agriculture research results received the most votes, followed by SARE-funded research and education on onfarm "systems" and on alternative and sustainable energy systems.

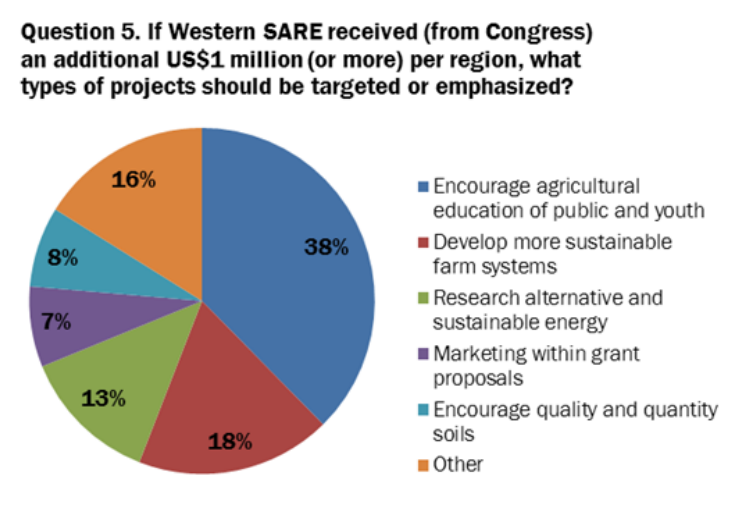

\section{BURNING ISSUE 6. How Can Western} SARE Overcome Barriers?

Conference attendees overwhelming voted for Western SARE to increase outreach (including electronic, printed, specialist-to-farmer, and farmer-to-farmer) to underserved groups, and to target calls for proposals toward underserved groups and provide simple illustrations of successful proposals.

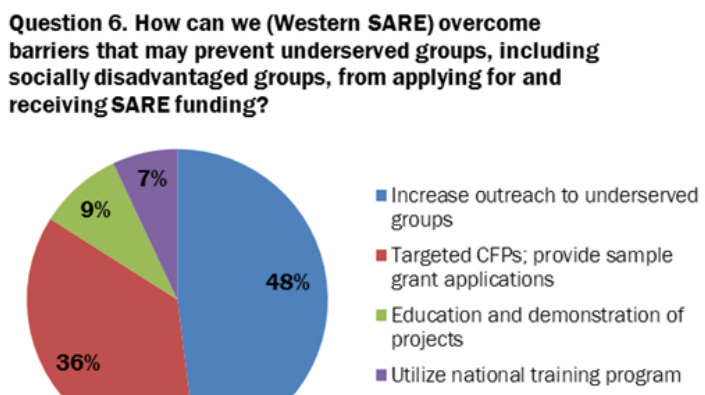

- Increase outreach to underserved groups

- Targeted CFPs; provide sample grant applications

Education and demonstration of projects

- Utilize national training program

What became apparent as we viewed the plethora of data collected from each conference were these top food systems concerns:

- Gaps in and lack of infrastructure development (such as slaughtering 
facilities, local incubator kitchens, small farm equipment pools, adequate capital, adequate energy transmission lines, and resilient transportation systems);

- The need for consumer education on the benefits of sustainable, locally grown foods and how to prepare them;

- Needed changes in policy, regulatory, institutional purchasing, and financing systems that are more supportive of and a catalyst for local food system development; and

- Pressing needs for training of beginning farmers and ranchers.

\section{Gaps in and Lack of Infrastructure Development} Infrastructure includes storage, livestock processing and other food processing and distribution facilities. Attendees in all or most subregions identified the need to have USDA-inspected facilities within driving distance to process livestock and poultry year-round. Without such facilities, livestock producers typically sell at auction, leaving them with few options for branding their products to participate in higher-value markets. Yet the regulatory environment makes creating locally based facilities quite challenging, as does the development of an effective business structure. To meet increasing consumer demand, farmers, ranchers, and small branded meat companies need appropriate-scale processing facilities along with the skills, inspection status, and other qualities to handle their products safely and to customer specifications.

Other infrastructure development needs acknowledged were increasing the availability and use of community-based certified kitchens, cold storage, food development centers, and other shared equipment that would serve regional needs - especially for small-scale producers. Transportation and distribution challenges were noted as affecting producers at both the small and midscale of production.

Consumer Education on the Benefits of Sustainable, Locally Grown Foods and How To Prepare Them More education should result in an increasing number of consumers who are dedicated to purchasing locally produced and marketed foods. This larger market will, in turn, increase the economic viability of producers and help develop alternative distribution and transportation systems. The consumers will also be eating healthier, fresher foods, making it a win-win for all.

Policy, Regulatory, Institutional Purchasing, and Financing Changes That Are More Supportive of and a Catalyst for Local Food System Development The input provided by the stakeholders is that the agriculture system as it is currently constructed has placed barriers in front of innovative and alternative methods for processing, distributing, and marketing food regionally.

\section{Training for Beginning Farmers and Ranchers}

With increased training for those who are starting a farm or ranching operation - especially those who do not come from such a background - there will be more assurance that our region will have enough farmers as current ones retire. Attendees discussed their belief that increasing the ability of beginning producers to succeed and increase their profit will strengthen the food system since oftentimes new producers are located closer to urban and suburban areas. Urban and peri-urban areas could also provide entry-level market opportunities for beginning farmers with limited access to capital.

The information gathered at the seven subregional conferences is unique to the Western SARE Region in regard to how food systems are typically looked at because many areas are remote from urban areas. Food systems work often assumes access to large urban markets, yet regions such as northeast Montana, the Four Corners region (where the states of Arizona, Colorado, New Mexico, and Utah meet), tribal lands, most of Alaska, the Pacific Islands, and parts of Wyoming are very far from large urban markets. We heard from stakeholders in these regions, in addition to those who live in or near urban areas, and cataloged their priorities for building stronger regional food systems. The Western SARE Region is unique in its vastness and diversity, yet even with this diversity we were able to determine common needs and concerns. 


\section{Conclusions}

One may ask how a competitive grants program such as Western SARE could address problems that are clearly beyond its congressionally mandated scope ("to enhance agricultural sustainability through competitive research/education grants"). For example, it is clear that agricultural infrastructure issues surfaced as key, quantifiable issues for more than one focus question at every subregional conference. Therefore the Western SARE Administrative Council prioritized infrastructure problems as something SARE research and education could address. In addition, a set of special Infrastructure Conferences were planned to further define the problems, suggest solutions, and encourage research proposals to address those problems. Western SARE, under USDA-NIFA policies, can neither directly work to change government policy nor issue grants for capital investments or operating costs for infrastructure facilities and equipment. However, Western SARE leaders felt that bringing leading farmers, ranchers, agency personnel, and key decision-makers together for a dialogue was surely within the SARE mandate. In retrospect, this has been very successful - and has certainly stimulated appropriate research and education proposals for Western SARE to evaluate for funding. The conferences also assisted in identifying other specific food systems issues that could be addressed by proposals to the Western SARE Center.

Significantly, Western SARE's administrative council has implemented major changes in its calls for proposals, the key elements by which proposals are rated for funding, and the very nature of the type of proposals that are solicited. Note that each of these address a need or suggestion that was illustrated in the previous figures. These changes include:

1. The development of a new multidisciplinary farm to fork "systems" emphasis in each major research and education grants program.

2. The clear acknowledgement, based upon subregional conference results, of the fact that most measured outcomes from "systems" research projects will require projects that span far beyond Western SARE's current three-year funding cycle.

3. The development of a new and clearly defined mechanism within the calls for proposals and the proposal review system to engender and foster longer-term research studies that can be renewed (multiple times if justified), based upon clearly measured outcomes, significant accomplishments, and positive external evaluations.

4. The reemphasis of the requirement for farmers and ranchers to be involved, from the start, in every type of SARE-funded project.

5. The number of required farmers and ranchers who were involved in a project was also increased.

6. The empowerment of the Western SARE Center's new communications specialist to increase efforts to reach out to disadvantaged communities.

7. The development of a long-term plan for ongoing research and education conferences (such as two Infrastructure Conferences and one Water Conference) to increase communication in and between all levels of SARE clientele (scientists, educators, farmers, ranchers, agricultural specialists, agribusiness, and farm lending organizations). This has already been shown to aid in the improvement of proposal specificity and quality.

8. The provision for a special US $\$ 50,000$ competitive call for research and education proposals targeted to the subregional conference area. These targeted calls for proposals immediately followed each subregional conference and were directed at the most significant research and education needs identified at each conference.

9. The increased support and funding for Farmer/Rancher grants and Professional/Producer grants as well as all other Western SARE Center competitive grants programs. 
10. The substantial increase in oversight, evaluation and expert support for all on-farm research and education projects.

11. The requirement for both an extension and outreach component and a built-in outside evaluation component in any new Western SARE competitive proposal that is funded.

12. The changing of the research and education grant funding schedule and associated deadlines so that each grant can be funded during the current crop year - even if Congress delays annual appropriations for as much as a year.

\section{Acknowledgements}

The Western SARE Center is one of four regional SARE Centers funded by Congress through the United States Department of Agriculture's National Institute for Food and Agriculture (USDA-NIFA). The authors are indebted to the entire staff of Western SARE who spent countless sleepless night-time hours compiling, sorting, transcribing, analyzing, and summarizing the firstday results from the Nominal Group Method Postit poster sheets. This allowed the second-day roundtable groups to immediately assess, comprehend, and critically discuss all high-ranking ideas from every table's first-day discussions and NGM voting. In addition, we wish to thank the over 700 participants in the round-table NGM process from the 11 contiguous Western states, Alaska, Hawaii, Guam, Northern Mariana Islands, Micronesia, and American Samoa. The depth and breadth of experiential information supplied to this study by these participants, from countless separate cultures and agricultural backgrounds, cannot be overstated.
Finally, Western SARE would like to acknowledge Dr. Barbara Rusmore of the Institute for Conservation Leadership for her invaluable assistance in designing the subregional conference framework and planning timeline. We also must acknowledge the incomparable assistance of Dr. Jerald "Jerry" R. DeWitt, whose masterful facilitation ensured the success of all Western SARE subregional conferences.

\section{References}

Delbecq, A. L., \& Van de Ven, A. H. (1971). A group process model for problem identification and program planning. Journal of Applied Behavioral Science, 7(4), 466-492. http://dx.doi.org/10.1177/002188637100700404

Delbecq, A. L., Van de Ven, A. H., \& Gustafson, D. H. (1975). Group techniques for program planning: A guide to nominal group and Delphi processes. Glenview, Illinois: Scott, Foresman.

Glass, J. J. (1979). Citizen participation in planning: The relationship between objectives and techniques. Journal of the American Planning Association, 45(2), 180-189. http://dx.doi.org/10.1080/01944367908976956

Place, N. T. (2007). Using nominal group techniques for helping new extension agents understand how to effectively involve advisory committee members. Journal of Extension, 45(1), 1IAW1. Retrieved from http://www.joe.org/joe/2007february/iw1.php

Sample, J. A. (1984). Nominal group technique: An alternative to brainstorming. Journal of Extension, 22(2), article 2IAW2. Retrieved from http://www.joe.org/joe/1984march/iw2.php

Schmoldt, L., \& Peterson, L. (2000). Analytical group decision making in natural resources: Methodology and application. Forest Science, 46(1), 62-75. 


\section{APPENDICES}

\section{Appendix A. Detailed Conference Methodology}

Western SARE used a unique modification of the Nominal Group Method that included several key elements:

- Utilizing large, round tables of semirandomized participants (8 to 10 participants each).

- Electronically distributing six focus questions prior to the meeting which were then discussed in distinct 40-minute sessions at the tables as the conference began.

- Using Delbecq's "Brainstorming of Ideas" at each table and recording responses to the focus questions on poster-size Post-it notes.

- Holding a round-robin sharing of ideas, facilitated after all ideas were assembled (and after similar ideas were combined).

- Allowing all participants 10 votes at the conclusion of the first day's discussions.

- Hosting an evening of relaxed conversation that separated the initial brainstorming from a second day of critical discussion and rankings.

- On the first evening, Western SARE staff summarizing all responses and vote totals electronically and providing them to all participants at the initiation of the second day's critical discussion of all tables' top-ranking ideas.

- Providing each table with ranked summaries of all tables' first-day ideas.

- Voting by all participants on a second ranking after similar ideas were combined and a full morning's critical discussion of all ideas took place.

- Creating a final ranking by compiling, collating, summarizing, and sorting ideas electronically prior to the second day's afternoon discussion and reflection by the Western SARE Administrative Council.

The council sat in front of the 10-20 roundtable groups to reflect and respond to audience questions regarding the final highest-ranked ideas.

- Posting ALL of the first day's brainstorming ideas on a website for each subregional NGM activity, along with the second day summaries. This reemphasized that all ideas were captured and that all comments were valuable to the Western SARE Administrative Council.

- Posting electronically (via Western SARE's website) the top-ranked ideas for each focus question at each subregional conference in a summary document after all conferences were concluded. This document was then discussed in depth at later administrative council meetings for appropriate action.

In crafting a conference format, planners began with basic questions:

- What are appropriate divisions for subregions?

- Who should be invited?

- How will the conferences be structured?

- How will responses be elicited from participants?

- How will information be gathered, processed, and used?

\section{Defining Subregions}

The Western SARE Region encompasses 17 political entities (13 states, two territories, and two Pacific island protectorates) that include a wide variety of geographical and ecological subregions - from mountain to desert and subarctic to tropical. The subregions defined for the conferences considered political, ecological and cultural divisions. Each subregion contained an easily definable entity or name tag: Oceania for the U.S. Pacific territories and protectorates, North Pacific (islands) for Hawaii, Midway, etc., Subarctic for Alaska's subarctic farming zones, Southwest for the arid Southwest states, Pacific Coast for California's large (Mediterranean) central valley and coastal agricultural zones, Pacific Northwest for the Pacific Northwest states, and High Plains for the High Plains and Intermountain states. 


\section{Attendance and Structure}

To ensure that attendees were drawn from representative sectors of agriculture (production, education, government, business, and nonprofit), Western SARE decided that attendance would be by invitation rather than open to all. A call for proposals issued in each subregion sought applicants who would help plan the conference, solicit local speakers, and develop lists of potential attendees. Specific invitations to potential attendees were sent by both email and postal mail. These attendees included farmers and ranchers with a known focus on sustainability components of their operations. Other specific attendees were sought from known commodity group leaders. These included specialty crop growers such as hop and wine grape growers in the Pacific Northwest and nut, fruit, and vegetable growers in California's Central and Coastal valleys. The regional SARE offices also sent invitations to the key leaders and agricultural specialists in state departments of agriculture, Farm Bureau, Farmer's Union, the USDA Natural Resources Conservation Services (NRCS), the USDA Agricultural Research Service (ARS), the land-grant university system, and local organic organizations and Sustainable Agriculture Working Groups (SAWGs). In addition, at least ten SARE grantees also attended each conference - including those who were willing to highlight their projects in posters that were displayed at the periphery of the conference. Total attendance at each conference was planned for between 100 and 140 key grassroots representatives.

Each conference followed a basic two-day structure. Day one included opening presentations by local speakers and SARE experts as well as a poster session and a half-day discussion of critical questions. Day two included a half-day of ranking and discussing responses, table leader reports, an open-microphone session, and responses by administrative council members.

To further ensure continuity among all seven subregional conferences, one person was chosen to moderate all the conferences. Serving in this capacity was Jerry DeWitt, former director of the Leopold Center for Sustainable Agriculture at Iowa State University.

\section{Eliciting Responses}

Western SARE solicited input from key constituents to develop a set of six questions that would serve as a stimulus and focus for discussion at each subregional conference. The resulting burning issue focus questions were designed to elicit broad feedback on issues and constraints. Asking the same questions at each conference provided continuity in responses, enabling comparisons among subregions. The approach was not meant to provide a statistical underpinning for conference evaluation, but rather to allow the administrative council to better equate and weigh responses from varied subregions.

\section{Subregional Conference Burning Issue Focus Questions}

1. What will be needed to create stronger local and regional food systems that are less reliant on imports from elsewhere?

2. What are the local and regional consumption and production trends in your local area?

3. The SARE program was commissioned, by Congress, to get its research results to the farmer and rancher. How can this process be improved?

4. What type of research, education and development projects will be necessary over the next 10 years to help economically sustain farming and the environment?

5. If Western SARE received (from Congress) an additional US $\$ 1$ million per region, what types of projects should be targeted or emphasized?

6. How can we (Western SARE) overcome barriers that may prevent underserved groups, including socially disadvantaged groups, from applying for and receiving SARE funding?*

\section{* This final question was not raised at the Pacific Subregional Conference, where all participants fell into the category of} "underserved." 
Western SARE leaders focused on several techniques for eliciting responses from participants. They facilitated and recorded roundtable discussions, applied the Nominal Group Technique for ranking issues raised, presented table-top reports from a representative chosen by the group at each table, held an openmicrophone session at the conference conclusion, and conducted surveys during and after the conference.

Extension educators - many of whom are state and protectorate professional development coordinators in the Western SARE Region - along with staff and administrative council members served as facilitators and recorders for tabletop discussions. They were trained on site and instructed to:

- ensure that every comment was recorded;

- give every participant an opportunity to speak; and

- draw out comments from all participants. 


\section{Appendix B. Cross-Subregion Results}

Table 1 summarizes the most significant data that was collected from the Western SARE Subregional Conferences. It details the issues that received the highest "votes" (via the nominal group methodology) across all of the conferences. It also denotes which subregional conference gave "voice" to each specific issue.

\section{Table 1. Major Ideas with Significant Votes Sorted by Burning Issue Focus Question Number}

\begin{tabular}{|c|c|c|}
\hline $\begin{array}{l}\text { Total Votes } \\
\text { Day } 2\end{array}$ & $\begin{array}{l}\text { Question 1: What will be needed to create stronger local and regional food systems } \\
\text { that are less reliant on imports from elsewhere? }\end{array}$ & Subregion \\
\hline 82 & $\begin{array}{l}\text { Educate and/or mentor students in kindergarten through high school on benefits of } \\
\text { growing own food and about agriculture }\end{array}$ & North Pacific \\
\hline 70 & $\begin{array}{l}\text { Develop local and/or regional infrastructure for financing, processing (small and } \\
\text { medium scale and/or mobile), cleaning, distribution, consulting }\end{array}$ & Pacific NW \\
\hline 61 & Educate the consumer and market the advantages of locally grown food & Subarctic \\
\hline 59 & Agriculture infrastructure (land and water) & North Pacific \\
\hline 55 & Regional livestock processing plants and infrastructure or mobile facilities & High Plains \\
\hline 55 & Farmer- and consumer-friendly regulations (relief from burdensome regulations) & High Plains \\
\hline 50 & $\begin{array}{l}\text { Availability of affordable agricultural land (land and water rights, labor and ownership } \\
\text { issues) }\end{array}$ & North Pacific \\
\hline 48 & $\begin{array}{l}\text { Educational programs for consumers, producers, facility owners, investors, schools, } \\
\text { chefs, and food services (on nutritional values, freshness, local economy, environment, } \\
\text { reduced transportation, growing livestock and produce) }\end{array}$ & High Plains \\
\hline 45 & Statewide training and outreach for beginning farmers and gardeners & Subarctic \\
\hline 43 & Infrastructure (e.g. processing, canneries, etc.) & Subarctic \\
\hline 43 & $\begin{array}{l}\text { Feasibility studies and/or research of alternative and/or local distribution channels; } \\
\text { financial and economic aspects; food and land trusts barriers; facilities and storage } \\
\text { issues; opportunities for meat processing }\end{array}$ & Pacific Coast \\
\hline 26 & Availability of processing facilities specifically for animals & Southwest \\
\hline $\begin{array}{l}\text { Total Votes } \\
\text { Day } 2\end{array}$ & $\begin{array}{l}\text { Question 2: What are the local and regional consumption and production trends in } \\
\text { your local area? }\end{array}$ & Subregion \\
\hline 84 & Demands for local and organic produce are increasing & North Pacific \\
\hline 63 & There is an increasing demand for local food & Subarctic \\
\hline 63 & Supply of local food is not adequate to meet demand - most food is imported & Subarctic \\
\hline 59 & Farmers reestablishing community linkages are capturing local demand for products & North Pacific \\
\hline 55 & $\begin{array}{l}\text { New market opportunities are growing, but there is a lack of supporting infrastructure } \\
\text { (storage, mills) }\end{array}$ & Pacific NW \\
\hline 52 & Fewer farmers statewide & North Pacific \\
\hline 49 & There is a lack of warehousing, storage, and processing capacity & Subarctic \\
\hline 42 & $\begin{array}{l}\text { Increased preference by consumers for locally grown, organic, farmers' markets, and } \\
\text { community-supported agriculture operations (CSAs) }\end{array}$ & High Plains \\
\hline 41 & More small- and large-scale gardens and small-scale animal production & Subarctic \\
\hline 40 & Not enough local protein sources & Oceania \\
\hline 29 & Local processing facilities and infrastructure & Southwest \\
\hline
\end{tabular}




\begin{tabular}{|c|c|c|}
\hline $\begin{array}{l}\text { Total Votes } \\
\text { Day } 2\end{array}$ & $\begin{array}{l}\text { Question 3: The SARE program was commissioned, by Congress, to get its research } \\
\text { results to the farmer and rancher. How can this process be improved? }\end{array}$ & Subregion \\
\hline 79 & $\begin{array}{l}\text { Disseminate more region-specific information (research results, locally adapted } \\
\text { cultivars or livestock, big ideas for small places, etc.) }\end{array}$ & Subarctic \\
\hline 55 & $\begin{array}{l}\text { Provide more money (stipends to attend conferences, research projects, organization } \\
\text { matches, etc.) }\end{array}$ & Subarctic \\
\hline 55 & $\begin{array}{l}\text { Farmer-to-farmer education and co-learning opportunities (field days, information- } \\
\text { exchange meetings, etc.) }\end{array}$ & Pacific Coast \\
\hline 48 & Provide info and help Cooperative Extension Service do its job better & Subarctic \\
\hline 43 & $\begin{array}{l}\text { Disseminate more information on Internet-based venues (blogs, email, social networks, } \\
\text { online courses, etc.) }\end{array}$ & Subarctic \\
\hline 40 & Not enough communications & Oceania \\
\hline 39 & On-farm trials, publications, tours, demonstrations, farmer-to-farmer events & Pacific NW \\
\hline 30 & Add youth-education component to grants & Southwest \\
\hline $\begin{array}{l}\text { Total Votes } \\
\text { Day } 2\end{array}$ & $\begin{array}{l}\text { Question 4: What types of research, education, and development projects will be } \\
\text { necessary over the next } 10 \text { years to help economically sustain farming and the } \\
\text { environment? }\end{array}$ & Subregion \\
\hline 76 & Soil improvement and sustainability (including composting) & Subarctic \\
\hline 92 & $\begin{array}{l}\text { How to reduce farm inputs, reduce fuel cost, efficiency modeling, on-farm fertilizer } \\
\text { production }\end{array}$ & North Pacific \\
\hline 61 & More collaborative projects to develop whole farm systems for the North Pacific & North Pacific \\
\hline 54 & Developing local infrastructure (processing, storage, suppliers, etc.) & Subarctic \\
\hline 52 & Energy-efficient, low-impact farming & Subarctic \\
\hline 51 & $\begin{array}{l}\text { Explore alternative food systems (including native systems, food sources, new varieties, } \\
\text { unconventional farming) }\end{array}$ & Subarctic \\
\hline 51 & Mobile and local processing & Pacific NW \\
\hline 48 & $\begin{array}{l}\text { Agricultural economics (identifying, evaluating, reducing, and managing the real costs of } \\
\text { agriculture, etc.) }\end{array}$ & Subarctic \\
\hline 47 & Support projects that develop regional foodsheds & Pacific NW \\
\hline $\begin{array}{l}\text { Total Votes } \\
\text { Day } 2\end{array}$ & $\begin{array}{l}\text { Question 5: If Western SARE received (from Congress) an additional US } \$ 1 \text { million (or } \\
\text { more) per region, what types of projects should be targeted or emphasized? }\end{array}$ & Subregion \\
\hline 76 & Using local sources of soil nutrients (compost, fish vegetation, etc.) to their best abilities & Subarctic \\
\hline 72 & $\begin{array}{l}\text { Energy efficiency and alternative energy for sustainable production methods for } \\
\text { producers (sustainable energy technology: solar heating and electrical power for } \\
\text { producers, do-it-yourself wind, solar, electric, and hot water systems; biofuels, } \\
\text { hydroponic) }\end{array}$ & Subarctic \\
\hline 69 & Invest in school gardens, elementary education, and consuming food in cafeterias & North Pacific \\
\hline 64 & $\begin{array}{l}\text { Education and involvement of youth on sustainable agriculture practices, agriculture in } \\
\text { general (includes kindergarten through high school), internships on farms and in } \\
\text { colleges }\end{array}$ & Subarctic \\
\hline 59 & Whole farm energy and nutrient systems & Pacific NW \\
\hline 58 & $\begin{array}{l}\text { Garden demonstration projects (local, community, apartments, school, tribal, and } \\
\text { village) of locally produced food, how to grow your own food, how to add value to } \\
\text { products }\end{array}$ & Subarctic \\
\hline 56 & $\begin{array}{l}\text { Agricultural research (including economic evaluations) of all aspects of sustainable } \\
\text { farming systems, including permaculture }\end{array}$ & Subarctic \\
\hline
\end{tabular}




\begin{tabular}{cll}
\hline $\begin{array}{c}\text { Total Votes } \\
\text { Day } \mathbf{2}\end{array}$ & $\begin{array}{l}\text { Question 6: How can we (Western SARE) overcome barriers that may prevent } \\
\text { receiving SARE funding? }\end{array}$ & Subregion \\
\hline 87 & More outreach to these groups with a funded position; travel to the areas & Subarctic \\
\hline 82 & Provide extra points to grant-writers who target minority groups in their grants & North Pacific \\
\hline 67 & $\begin{array}{l}\text { Provide funding support for mentors to build community relationships and to } \\
\text { collaboratively apply for grants }\end{array}$ & Pacific NW \\
\hline 63 & Education and demonstration projects & Subarctic \\
\hline 62 & $\begin{array}{l}\text { Western SARE is the largest and most diverse SARE region; it should get more dollars } \\
\text { for funding }\end{array}$ & North Pacific \\
\hline 59 & Promote farming as a viable vocation and science & Subarctic \\
\hline 58 & $\begin{array}{l}\text { Employ a liaison to work with farmers and others on grant applications to help get } \\
\text { things going }\end{array}$ & Subarctic \\
\hline 58 & $\begin{array}{l}\text { Partner with regional groups, tribes, communities, extension, Farm Service Agency } \\
\text { (FSA), etc. }\end{array}$ & Subarctic \\
\hline 37 & Develop partnerships with organizations serving these communities & Southwest \\
\hline 35 & Provide funding to local entities to target locally identified, underserved audiences & High Plains \\
\hline
\end{tabular}

